\title{
Pelatihan Computer Based Test (CBT) Ujian Nasional Untuk Siswa SMK di Lombok Timur
}

\author{
Baiq Desi Dwi Arianti*1 ${ }^{1}$, Yosi Nur Kholisho ${ }^{2}$, Kholida Ismatulloh ${ }^{3}$, Rasyid Hardi W. ${ }^{4}$, \\ M. Zamroni Uska ${ }^{5}$, Ahmad Fathoni ${ }^{6}$, Jamaluddin ${ }^{7}$ \\ Email: ariantibaiq@hamzanwadi.ac.id \\ Pendidikan Informatika, Fakultas MIPA, Universitas Hamzanwadi ${ }^{1,2,3,4,5,6,7}$
}

\section{DOI: 10.29408/ab.v1i1.2408}

\begin{abstract}
Abstrak: Kegiatan Pengabdian kepada Masyarakat (PkM) ini bertujuan untuk memberikan pemahaman kepada siswa SMK mengenai proses dan cara kerja aplikasi Ujian Nasional Berbasis Komputer(UNBK), sehingga siswa lebih siap dalam menghadapi UNBK 2017 mendatang. Metode yang digunakan untuk mencapai tujuan tersebut adalah ceramah dan praktik menggunakan aplikasi Computer Based Test (CBT) dengan cara demontrasi aplikasi CBT sebagai simulasi UNBK. Luaran kegiatan ini adalah siswa mampu mengoprasikan aplikasi UNBK dengan baik, sehingga pada saat pelaksanaan UNBK yang sebenarnya siswa tidak kesulitan; artikel ilmiah (publikasi nasional). Hasil kegiatan yang telah dicapai antara lain memberikan banyak manfaat pada siswa SMK mitra, siswa mampu menguasai dan menggunakan aplikasi UNBK, siswa lebih siap menghadapi UNBK tahun 2017.
\end{abstract}

Kata kunci: Computer Based Test (CBT), Ujian Nasional Berbasis Komputer (UNBK), Ujian Nasional

\section{PENDAHULUAN}

Perubahan dan perkembangan teknologi yang sangat cepat dewasa ini memerlukan dukungan dalam bentuk pembelajaran dan penciptaan baru yang berkelanjutan dari berbagai ide dan keterampilan. Perubahan dan perkembangan ini, berdampak pada kehidupan manusia di segala bidang, salah satunya yaitu bidang pendidikan. Perkembangan ilmu pengetahuan dan teknologi telah mendorong teknologi pendidikan untuk ikut berkembang. Perkembangan tersebut telah mengilhami penemuan beberapa alat komunikasi dan teknologi untuk meningkatkan perkembangan informasi secara masal dan cepat. Untuk mendukung perkembangan tersebut diperlukan adanya media pembelajaran. Bentuk media pembelajaran saat ini sangat beragam. Salah satu media pembelajaran paling populer saat ini adalah teknologi internet.

Internet merupakan jaringan antara atau penghubung, sehingga internet dapat diartikan sebagai hubungan antara berbagai jenis komputer dan jaringan di dunia yang berbeda sistem operasi maupun aplikasinya dimana hubungan tersebut memanfaatkan kemajuan komunikasi (telepon dan satelit) yang menggunakan protokol standar dalam berkomunikasi yaitu protokol TCP/IP (Transmission Control / Internet Protocol) (Supriyanto \& Muhsin, 2008). Internet sangat membantu dunia pendidikan, karena dengan adanya internet dapat diperoleh informasi terbaru dari seluruh penjuru dunia (Murdiono, 2010). Proses pendidikan berubah secara signifikan dalam dua dekade terakhir ini karena internet. Internet sebagai e-learning menjadi sumber pengetahuan yang penting untuk proses pembelajaran jangka panjang. Meskipun sumber belajar sering dianggap sebagai kunci kekayaan intelektual dalam dunia pendidikan tinggi yang kompetitif, akan tetapi semakin banyak lembaga dan individu yang membagikan 


\section{ABSYARA: JURNAL PENGABDIAN PADA MASYARAKAT BIDANG PENDIDIKAN, SAINS, DAN TEKNOLOGI}

Vol. 1 No. 1, Juli 2020, Hal. 22-32

pengetahuan secara digital melalui internet secara terbuka dan gratis sebagai Open Educational Resources (OER) (Virtič, 2012). Dengan bantuan internet pengguna dapat mendapatkan akses keberbagai macam sumber informasi di berbagai macam sistem jaringan, seperti jaringan perpustakaan elektronik, kamus elektronik, majalah dan koran elektronik dan sebagainya. Internet menyediakan akses yang mudah dalam hal informasi dan komunikasi. Kelebihan internet yang lain tidak hanya terletak pada biaya yang lebih murah akan tetapi juga waktu yang diperlukan untuk memperoleh informasi yang dibutuhkan juga jauh lebih singkat, selain itu ketepatan dan kualitas infromasi yang bagus juga merupakan kelebihan dari internet itu sendiri (Özad \& Kutoğlu, 2010).

Di Indonesia, pemanfaatan penggunaan teknologi internet sebagai teknologi pembelajaran telah lama dilakukan. Penggunaan teknologi pembelajaran semakin kuat pengaruhnya seiring dengan perkembangan teknologi informasi dan komunikasi (TIK) (Suryadi, 2015). Pemanfaatan TIK dalam proses pembelajaran dilakukan dalam berbagi bentuk, antara lain penyediaan bahan ajar secara online yang biasanya disimpan dalam bentuk buku atau artikel di internet, program Computer Assisted Learning, bahan alat peraga atau simulasi, pembelajaran Moodle dan Facebook serta pembelajaran jarak jauh (sekolah terbuka) (Darmawan \& Bariyah, 2015). Selain itu, pembelajaran yang menggunakan TIK terbukti memiliki hasil yang lebih baik jika dibandingkan dengan pembelajaran konvensional (Kholisho \& Arianti, 2016). Pemanfaatan TIK tidak hanya dapat digunakan sebagai sumber pencarian materi pembelajaran saja, akan tetapi dapat digunakan sebagai alat untuk mengukur pencapaian peserta didik (penilaian) dalam proses pembelajaran yang telah dilaksanakan. Penilaian dalam proses pembelajaran dibedakan menjadi tiga, yaitu sebagai alat untuk mendeteksi kesulitan belajar (assessment as learning), penilaian proses pembelajaran (assessment for learning) dan penilaian untuk mengukur pencapaian hasil belajar (assessment of learning) (Bennett \& Gitomer, 2010).

Penilaian dilaksanakan sebagai upaya melayani dan mendeteksi kesulitan belajar yang dialami peserta didik. Dari hasil penilaian tersebut dapat diketahui materi atau kompetensi mana saja yang belum dipahami atau dikuasai oleh peserta didik. Penilaian tersebut lebih mengukur pencapaian peserta didik selama proses pembelajaran di tingkat kelas dan pada akhir pembelajaran peserta didik dalam jenjang pendidikan dilakukan ujian akhir. Tujuan ujian akhir adalahh untuk memperoleh gambaran pencapaian kompetensi peserta didik selama mengikuti pendidikan yang meliputi aspek pengetahuan, keterampilan dan sikap (Basuki \& Hariyanto, 2014).

Kemendikbud melalui Badan Standar Nasional Pendidikan (BSNP) mengeluarkan peraturan BSNP Nomor: 0034/BNSP/XII/2015 tentang prosedur operasional standar penyelenggaraan ujian nasional tahun pelajaran 2015/2016. Pada tahun 2015 UN dilaksanakan dalam dua bentuk yaitu tertulis (paper and pencil test - PBT) dan berbasis komputer (computerbased test - CBT) dengan bentuk soal pilihan ganda. Ujian Nasional Tahun 2015 yang menerapkan ujian berbasis komputer disebut UNBK (Ujian Nasional Berbasis Komputer) (BSNP Indonesia, 2015). UNBK sendiri merupakan ujian yang relatif setara dengan ujian 


\section{ABSYARA: JURNAL PENGABDIAN PADA MASYARAKAT \\ BIDANG PENDIDIKAN, SAINS, DAN TEKNOLOGI}

Vol. 1 No. 1, Juli 2020, Hal. 22-32

tertulis seperti yang selama ini dilakukan. Perbedaanya hanya terletak pada penggunaan alat pendukung ujian yang tadinya pensil dan kertas, digantikan oleh komputer. UNBK dilaksanakan untuk meminimalisir resiko kecurangan pada pelaksanaan ujian nasional secara tertulis (Arief \& Suryani, 2016).

Permasalahan yang dihadapi oleh pemerintah adalah keterbatasan fasilitas, akan tetapi pemerintah mengatasi permasalahan tersebut dengan menggabungkan beberapa sekolah yang tidak memiliki fasilitas yang lengkap akan melaksanakan UNBK dibeberapa pos atau sekolah yang telah memilik fasilitas yang lebih lengkap. Permasalahan lain yang dihadapi oleh pemerintah adalah tidak semua siswa memiliki pengetahuan tentang komputer meskipun telah diuraikan di atas bahwa perkembangan teknologi sangat pesat. Tidak sedikit siswa yang tidak mengerti bagaimana cara menggunakan komputer untuk ujian nasional, apa lagi siswa-siswa yang berada di daerah pelosok, bahkan tidak menutup kemungkinan bahwa siswa-siswa yang sekolah didaerah perkotaan juga kurang faham bagaimana ujian nasional berbasis komputer tersebut dilaksanakan, bagaimana bentuk dari aplikasi yang digunakan dan sebagainya (Priyono, et al., 2016). Selain itu masalah lain yang dihadapi dalam pelaksanaan UNBK tahun 2016 di beberapa daerah adalah singkronisasi server yang gagal (Hermawan, 2016). Walapun demikian, ada beberapa sekolah yang siswanya sudah siap secara mental dan pengetahuan untuk melaksanakan UNBK secara online (Sailan, 2016).

Lombok Timur sebagai salah satu kabupaten yang memiliki jumlah sekolah untuk tingkat SMA sederajat yang banyak, memiliki pekerjaan rumah yang besar dalam menjalankan UNBK untuk tahun 2017 ini. Karna pada tahun 2016, dari jumlah total keseluruan sekolah SMA sederajat baik sekolah negri ataupun swasta sebanyak 273 sekolah, hanya 7 sekolah saja yang menggunakan sistem ujian UNBK. Jumlah keseluruhan sekolah untuk MA/SMA ada 208 sekolah (181 swasta dan 27 negri) hanya 1 sekolah negri yaitu SMAN 1 Aikmel yang menggunakan UNBK sebagai ujian nasional, sedangkan untuk SMK yang jumlah keseluruhannya ada 65 sekolah (11 negri dan 54 swasta) hanya 6 sekolah yang menggunakan UNBK (LombokFM, 2016). Dari rasio perbandingan tersebut maka perlu diadakan pembinaan atau pembimbingan dari awal untuk para siswa peserta UN tahun 2017 mendatang. Perlu usaha yang sangat keras dari berbagai kalangan demi suksesnya UNBK tahun 2017, apalagi target pemerintah pada tahun 2018 semua sekolah menengah atas sederajat serentak menggunakan sistem UNBK untuk ujian nasional (Okezone, 2017). Keterbatasan sarana dan prasarana dalam pelaksanaan UNBK di Kabupaten Lombok Timur menjadi permasalahan utama bagi pelaksanaan UNBK mendatang (2017). Tidak semua sekolah memiliki fasilitas untuk pelaksanaan UNBK tahun 2017, selain itu banyak siswa yang belum memahami betul cara menggunakan aplikasi UNBK, karena sebelumnya tidak banyak dilakukan pelatihan penggunaan aplikasi simulasi UNBK. Oleh karena itu perlu diadakannya pelatihan penggunaan aplikasi CBT sebagai simulasi UNBK tahun 2017.

Pelatihan ini diharapkan dapat meningkatkan pemahaman dan keterampilan siswa-siswi SMK mitra mengenai proses dan cara kerja aplikasi UNBK, sehingga siswa lebih siap dalam menghadapi UNBK tahun 2017 mendatang. 


\section{METODE PELAKSANAAN}

\section{Waktu dan Lokasi}

Pelaksanaan kegiatan pengabdian kepada masyarakat (PKM) ini dilaksanakan dari bulan Februari sampai dengan bulan Maret tahun 2017.

Lokasi pelaksanaan pengabdian kepada masyarakat dilakukan di 3 sekolah, yaitu SMKN 1 Sikur, SMK NW Kumbung, dan SMK NW Renco. Ketiga lokasi ini dipilih karena sekolahsekolah ini sebelumnya telah dilakukan pelatihan secara berkala dalam bidang komputer oleh mahasiswa Pendidikan Informatika Universitas Hamzanwadi, selain itu sekolah-sekolah ini juga memiliki fasilitas memadai untuk dijadikan tempat pelaksanaan kegiatan PkM yaitu tersedianya laboratorium komputer dan jaringan internet.

Peserta yang mengikuti kegiatan pelatihan ini difokuskan untuk siswa kelas XII yang berasal dari beberapa sekolah. Untuk lebih jelasnya dapat dilihat dari table berikut ini:

Table 1. Peserta PkM

\begin{tabular}{cllc}
\hline No & Lokasi Pelaksanaan & \multicolumn{1}{c}{ Asal Sekolah } & $\begin{array}{c}\text { Jumlah } \\
\text { Peserta }\end{array}$ \\
\hline 1 & SMKN 1 Sikur & - SMKN 1 Sikur & 136 \\
& & - SMK Yayasan Pendidikan Islam Santong & 55 \\
& & - SMK Qurrota A'yun NW Joben & 11 \\
& & - SMK Al-Ijtihad Masbagik & 6 \\
& & - SMK Al-Mujidiyah NW Kesik & 14 \\
2. & SMK NW Kumbung & SMK NW Kumbung & 46 \\
3. & SMK NW Renco & SMK NW Renco & 8 \\
\hline
\end{tabular}

\section{Prosedur pelaksanaan}

Persiapan pelaksanaan dimulai dari bulan Februari. Mulai dari perencanaan, pembuatan proposal, pemilihan mahasiswa yang akan mengikuti kegiatan PkM ini, penyeleksian sekolah mitra, perizinan dan evaluasi hasil. Pada tahap perencanaan tim dosen dan tim mahasiswa menganalisis kebutuhan kegiatan seperti modul, media dan instrument lainnya.

Pelaksanaan kegiatan dilaksanakan selama 3 hari. Hari pertama untuk pesiapan tempat dan alat. Hari kedua dan ketiga untuk pelatihan. Pelaksanaan kegiatan pelatihan dilakukan menjadi beberapa sesi perharinya untuk sekolah yang memiliki jumlah peserta yang banyak. Setiap sekolah mitra akan didampingi oleh 2 orang dosen dan beberapa mahasiswa.

Untuk mencapai tujuan kegiatan PKM ini digunakan 2 metode pelaksanaan, yaitu:

1. Ceramah

Metode ceramah digunakan dalam penyampaian materi-materi tentang CBT. Pelatihan difokuskan pada siswa/siswi kelas XII yang akan menempuh ujian nasional. Pemateri 


\section{ABSYARA: JURNAL PENGABDIAN PADA MASYARAKAT \\ BIDANG PENDIDIKAN, SAINS, DAN TEKNOLOGI}

Vol. 1 No. 1, Juli 2020, Hal. 22-32

dan peserta pelatihan akan diberikan modul atau materi pelatihan agar proses penyerapan materi pelatihan kepada siswa menjadi lebih maksimal.

2. Praktik

Tahap selanjutnya adalah peserta pelatihan diberikan pelatihan cara menggunakan aplikasi CBT secara tahap demi tahap. Tahap akhir adalah peserta pelatihan akan melakukan menjawab soal pada aplikasi CBT sebagai simulasi dalam menghadapi soal pada ujian nasional mendatang. Proses pelatihan dalam tahapan praktik dilakukan pada laboratorium komputer atau laptop siswa sesuai ketersediaan prasarana komputer disekolah, dalam pelatihan ini tidak menutup kemungkinan peneliti akan menyediakan sarana yang dibutuhkan dalam pelatihan ini.

Metode pengambilan data dilakukan melalui pengamatan selama kegiatan. Hasil pengamatan dan temuan masalah akan dicatat oleh dosen dan mahasiswa. Kemudian hasil tersebut akan dievaluasi untuk mengetahui apakah kegiatan ini berhasil atau tidak. Indicator keberhasilan kegiatan yang akan dinilai diambil dari kehadiran, keseriusan, respon dan antusiasme peserta selama mengikuti kegiatan pelatihan ini. Selanjutnya hasil tersebut akan disusun menjadi laporan akhir kegiatan.

Adapun langkah-langkah pelaksanaan untuk lebih ringkasnya dapat dilihat pada gambar berikut ini:

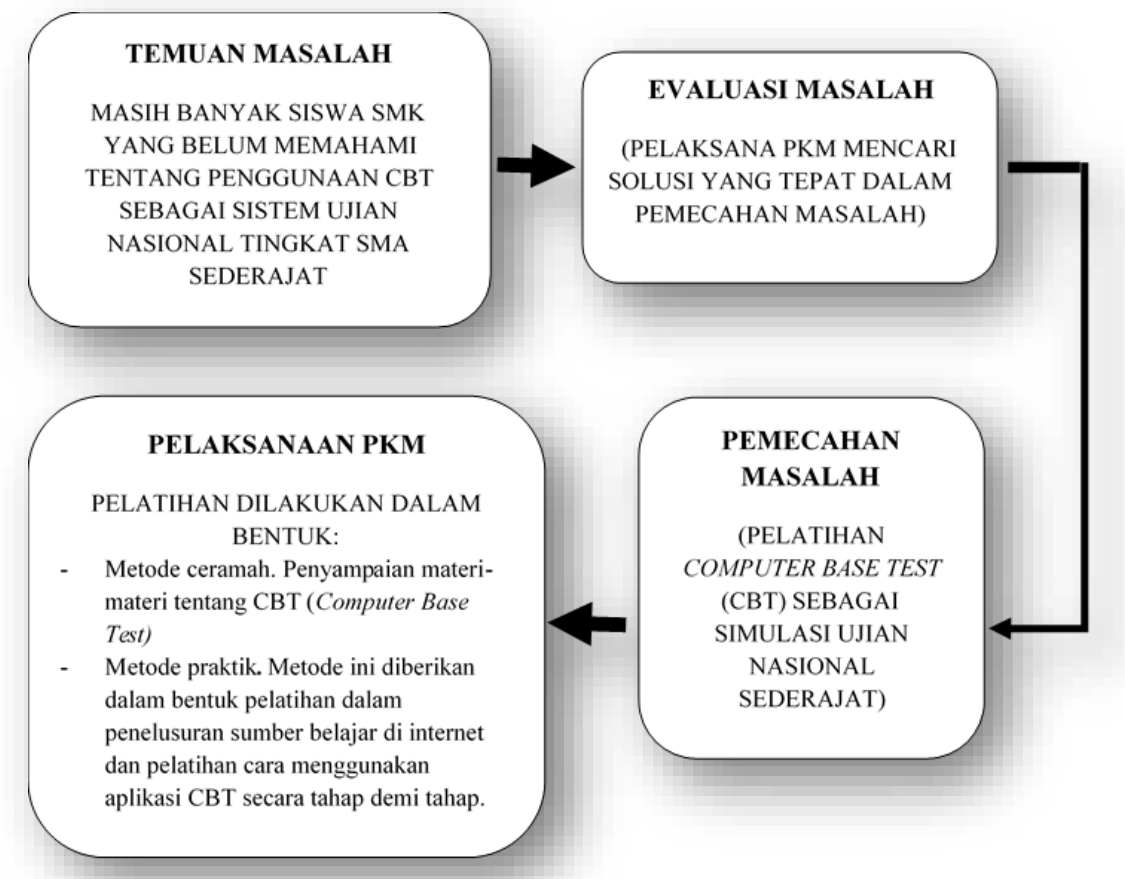

Gambar 1. Bagan alur pelaksanaan kegiatan PKM

\section{HASIL DAN PEMBAHASAN}

\section{HASIL}

Pelaksanaan kegiatan inti pelatihan di masing-masing sekolah dilakukan selama 3 hari. Hari pertama untuk persiapan tempat dan alat. Hari kedua dan ketiga untuk kegiatan pelatihan 


\section{ABSYARA: JURNAL PENGABDIAN PADA MASYARAKAT BIDANG PENDIDIKAN, SAINS, DAN TEKNOLOGI}

Vol. 1 No. 1, Juli 2020, Hal. 22-32

yang dibagi menjadi beberapa sesi karena jumlah peserta disalah satu sekolah cukup banyak. adapun tahap-tahap pelaksanaanya adalah sebagai berikut: (1) pengecekan lab. Komputer dan peralatan lainnya, (2) Absensi Peserta, (3) Perkenalan mahasiswa dan dosen, (4) Penjelasan tentang UNBK dan aplikasinya, (5) Langkah-langkah untuk login peserta, (6) Cara menjawab soal dan trik-triknya, (7) Latihan simulasi UNBK, (7) Evaluasi hasil simulasi (wawancara)

1. SMKN 1 Sikur

Di SMKN 1 Sikur menggunakan 2 lab. komputer untuk pelaksanaan kegiatan ini yaitu lab. multimedia dan lab TKJ dengan kapasitas komputer sebanyak 40 unit. Di setiap lab dibagi menjadi 3 sesi setiap harinya. Sesi pertama dimulai dari pukul 07.30 - 09.30, sesi kedua pukul 10.30 - 12.30, dan sesi ketiga pukul $14.00-16.00$.

a. Hari pertama

Pada hari pertama dilakukan persiapan tempat dan alat kegiatan. Mahasiswa dan dosen melakukan pengecekan perangkat komputer yang akan digunakan pada kegiatan inti. Terdapat beberapa komputer yang belum terkoneksi dengan server, sehingga perlu dilakukan pengkoneksian kembali.

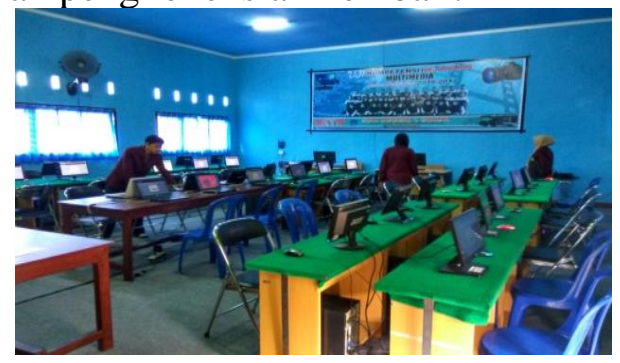

Gambar 2. Pengecekan kondisi komputer di lab. Multimedia

b. Hari kedua

Hari kedua pada setiap sesinya dimulai dengan melakukan absensi untuk kehadiran peserta. Selanjutnya perkenalan mahasiswa dan dosen serta maksud dan tujuan dari kegiatan. Setelah itu dosen akan melakukan persentasi cara penggunaan aplikasi UNBK, kemudian para peserta akan mulai melakukan praktik penggunaan aplikasi yang didampingi oleh mahasiswa. Jika ditemukan kendala mahasiswa akan membantu untuk memberikan arahan pada peserta pelatihan. Kemudian pada akhir sesi diadakan sesi tanya jawab untuk evaluasi hasil. Peserta berasal dari SMKN 1 Sikur dan SMK Yayasan Pendidikn Islam Santong, SMK Qurrota A'yun NW Joben, SMK Al-Ijtihad Masbagik dan SMK Al-Majidiyah NW Kesik

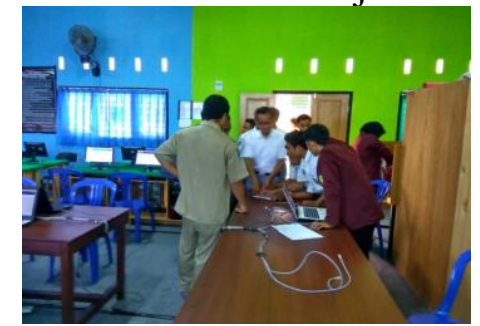

Gambar 3. Absensi Peserta

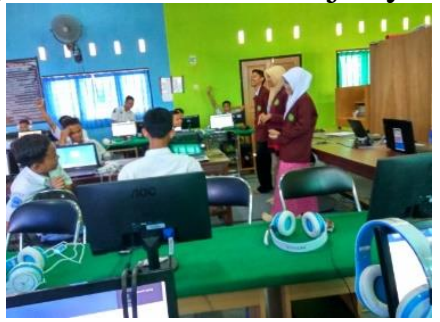

Gambar 4. Perkenalan Tim

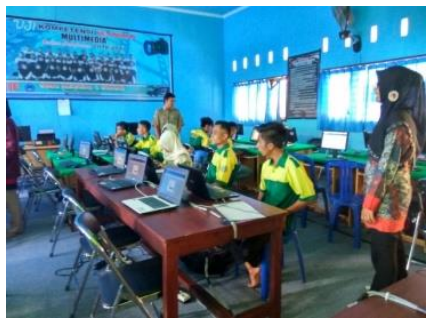

Gambar 5. Persentasi Materi 


\section{ABSYARA: JURNAL PENGABDIAN PADA MASYARAKAT}

BIDANG PENDIDIKAN, SAINS, DAN TEKNOLOGI

Vol. 1 No. 1, Juli 2020, Hal. 22-32

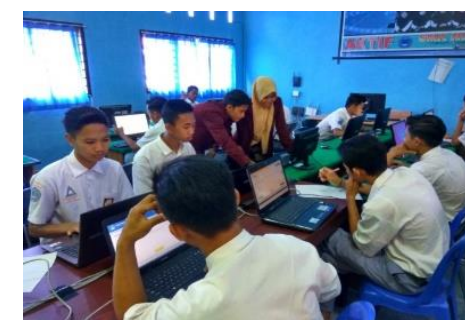

Gambar 6. Tim memerikas komputer yang mengalami eror ketika kegiatan berlangsung

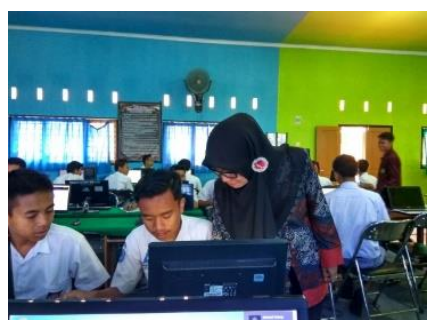

Gambar 7. Tim memberikan arahan kepada peserta

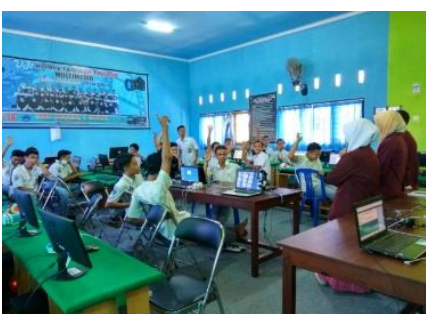

Gambar 8. Evaluasi dan tanya jawab

Temuan: pada hari pertama jumlah keseluruhan peserta adalah 223 siswa, akan tetapi yang hadir sebanyak 175 siswa dan tidak hadir sebanyak 48 siswa. Terdapat eror di beberapa komputer ketika pelatihan sedang berlangsung, seperti koneksi ke server yang terputus, kesalahan memasukkan token oleh peserta, selain itu listrik sempat padam ketika kegiatan sedang berlangsung, akan tetapi semua kendala tersebut dapat teratasi oleh Tim. Dari hasil evaluasi ditemukan bahwa para peserta beryukur dengan adanya kegiatan ini. Siswa menyatakan bahwa melalu kegiatan ini pengetahuan tentang system UNBK bertambah, dan siswa merasa bahwa kekawatiran siswa dapat berkurang.

c. Hari ketiga

Pada hari ketiga, tahapan-tahapan kegiatan sama dengan hari kedua.

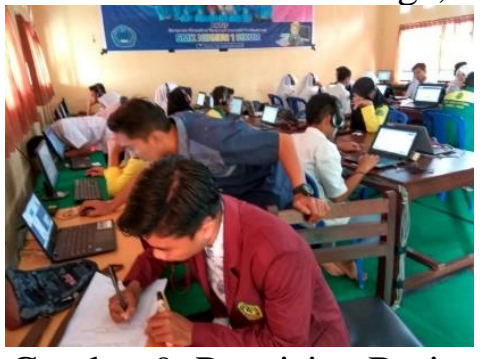

Gambar 9. Pengisian Berita Acara

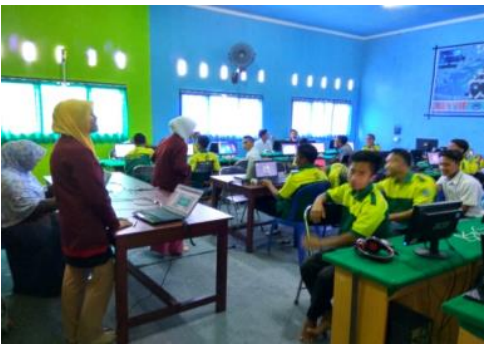

Gambar 12. Wawancara dan evaluasi

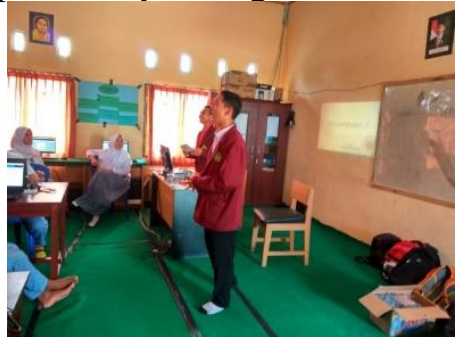

Gambar 10. Peresentasi materi

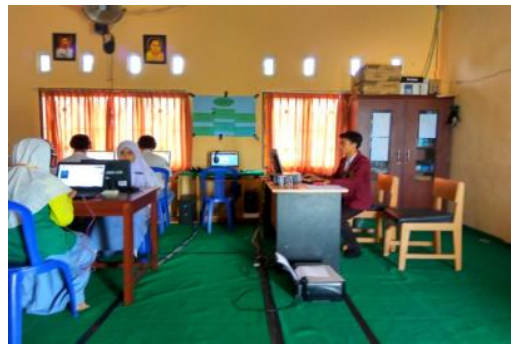

Gambar 13. Pengontrolan Komputer Induk (Server)

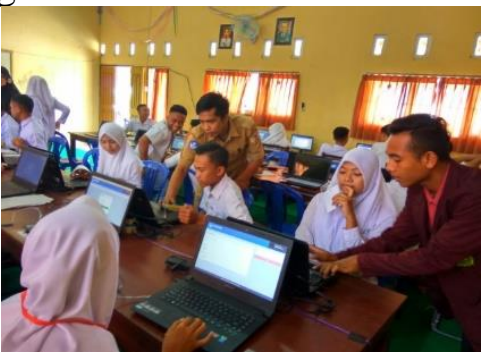

Gambar 11. Tim membantu peserta ketika terjadi kesalahan

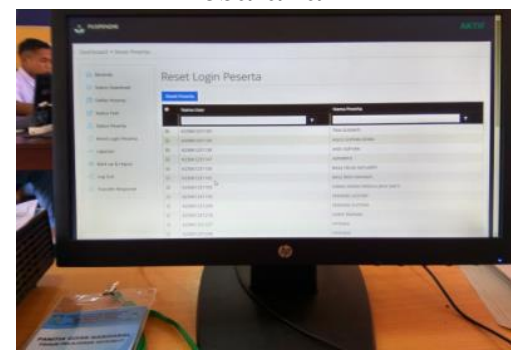

Gambar 14. Tampilan halaman reset login peserta pada komputer induk

Temuan: pada hari ketiga jumlah peserta sebanyak 187 siswa, hadir sebanyak 154 siswa, tidak hadir sebanyak 33 siswa. Kesalahan di hari ketiga lebih bisa diminimalisir. Meski terjadi 


\section{ABSYARA: JURNAL PENGABDIAN PADA MASYARAKAT BIDANG PENDIDIKAN, SAINS, DAN TEKNOLOGI}

Vol. 1 No. 1, Juli 2020, Hal. 22-32

beberapa kesalahan ketika peserta login ke aplikasi. Secara keseluruhan hari ketiga berjalan lebih lancar dibandingkan hari kedua.

2. SMK NW Kumbung

Dalam pelaksanaan pelatihan simulasi UNBK pada SMK NW Kumbung dilaksanakan dari tanggal $6-7$ Maret 2017. Tim PkM terdiri dari 6 orang mahasiswa dan 2 orang dosen sebagai koordinator. Jumlah peserta pelatihan adalah 46 siswa yang terdiri dari 23 peserta jurusan Teknik Komputer dan Jaringan (TKJ), 9 peserta jurusan Tata Busana dan 14 peserta dari jurursan Otomotif. Pelaksanaan pelatihan dibagi menjadi 3 sesi setiap harinya, agar hasil yang diperoleh lebih baik. Ruangan yang digunakan sebagai tempat pelatihan adalah labolatorium TKJ. Kegiatan dilakukan dari jam 07.30 - 16.00.

Tidak ditemukan kendala yang berarti pada kegiatan pelatihan, baik pada hari pertama maupun kedua. Peserta juga bertanya secara aktif, sehingga suasana pelatihan berjalan kondusif. Simulasi dilakukan secara berulang-ulang agar para peserta dapat mengingat dengan jelas, sehingga diharapkan pada saat UNBK dilaksanakan peserta sudah menguasai perangkat lunak yang digunakan.

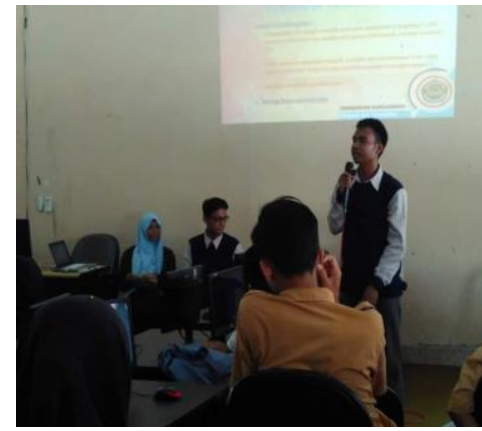

Gambar 15. Tim melakukan persentasi kepada peserta pelatihan

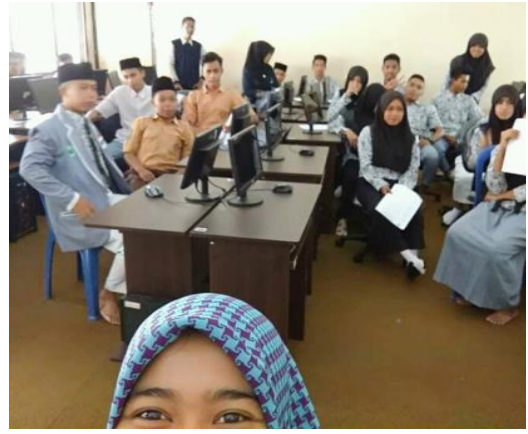

Gambar 16. Sesaat sebelum melakukan sesi diskusi dan tanya jawab

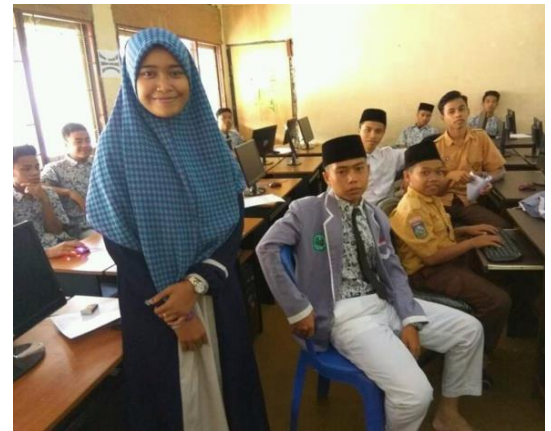

Gambar 17. Peserta siap melakukan praktik menggunakan aplikasi simulasi UNBK

3. SMK NW Renco

Kegiatan Pengabdian kepada Masyarakat (PkM) di SMK NW Renco dilaksanakan selama 2 hari yaitu pada tanggal 14 - 15 Maret 2017. Pelaksanaan kegiatan ini dilakukan oleh 5 orang mahasiswa dan 1 dosen sebagai koordinator dan pengawas kegiatan.

Peserta pelatihan simulasi di SMK ini terbilang sedikit, dikarenakan rombel SMK NW Renco kelas XII untuk tahun ini terbilang kecil yaitu hanya 8 orang siswa dengan jurusan Teknik Komputer dan Jaringan. Akan tetapi hal ini menjadikan kegiatan simulasi berjalan sangat kondusif. Pada hari pertama kegiatan yang dilakukan yaitu observasi peserta pelatihan. Dikarenakan julah peserta yang terbilang kecil, observasi secara individu dapat dilakukan. Observasi dilakukan untuk meilhat sejauh mana pengetahuan peserta mengenai UNBK. Setelah itu baru dilanjutkan dengan pemberian materi secara umum dari cara login sampai pemanfaatan waktu menjawab soal dengan baik.

Diawal kegiatan, tim PkM (mahasiswa) memberikan pengarahan mengenai apa itu CBT, kemudian tim memasuki teori konsep dan aturan pada saat pelaksanaan CBT (UNBK). 


\section{ABSYARA: JURNAL PENGABDIAN PADA MASYARAKAT BIDANG PENDIDIKAN, SAINS, DAN TEKNOLOGI}

Vol. 1 No. 1, Juli 2020, Hal. 22-32

Setiap penyampaian teori selesai langsung diikuti dengan praktikum, sehingga ingatan peserta pelatihan masih kuat ketika praktik dilakukan. Peserta pelatihan sangat aktif dalam mengikuti kegiatan ini, terbukti dengan munculnya banyak pertanyaan dari peserta kepada tim PkM. Kegiatan pelatihan UNBK dilaksanakan hanya sampai jam 12.00 saja.

Pada hari kedua, kegiatan yang dilakukan tidak jauh berbeda dengan hari pertama, hanya pada hari itu simulasi dilakukan berkali-kali dengan mata pelajaran yang berbeda, sehingga peserta pelatihan semakin terbiasa dengan perangkat lunak yang digunakan. Setelah kegiatan pelatihan simulasi selesai dilakukan, kemudian dilanjutkan dengan kegiatan melatih guru-guru mata pelajaran untuk menggunakan perangkat lunak yang akan digunakan dalam ujian sekolah. Para guru diajarkan dari bagaimana cara login pengguna sampai cara mengunggah soal dan jawaban serta berbagai macam fungsi-fungsi atau kegunaan konten-konten yang terdapat pada perangkat lunak tersebut.

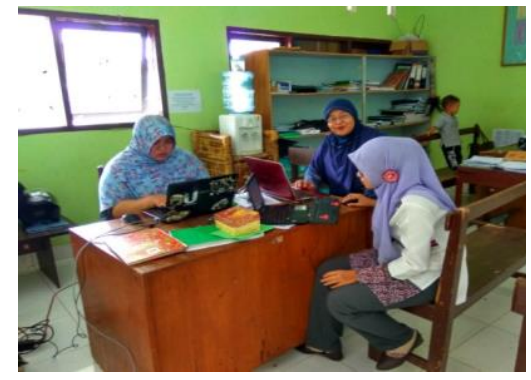

Gambar 17. Pelatihan guru menggunakan aplikasi UNBK yang dikembangkan yang akan digunakan sebagai aplikasi ujian sekolah



Gambar 18. Mahasiswa melakukan persiapan

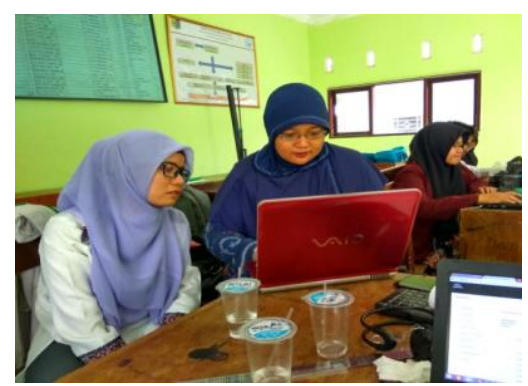

Gambar 19. Tim mempersiapkan aplikasi UNBK yang dikembangkan

\section{PEMBAHASAN}

Kegiatan PkM yang melibatkan 3 sekolah kejuruan ini ditemukan beberapa kendala, yaitu server yang eror dan sulitnya koneksi server, ditambah lagi dengan adanya pemadaman listrik. Dari ketiga sekolah tersebut, SMKN 1 Sikur paling banyak ditemukan kendala, ini dikarenakan jumlah peserta yang ikut pelatihan ini paling banyak. Untungnya anggota tim terpusat atau paling banyak di SMKN 1 Sikur, sehingga meskipun banyak didapati kendala teknis, tim dapat mengatasi hal tersebut dengan cepat. Sekolah berharap kegiatan dapat berkelanjutan tihap tahunnya. Dari hasil evaluasi, peserta merasa kegiatan ini sangat bermanfaat bagi siswa. Para peserta merasa lebih siap dalam menghadapi UNBK mendatang.

Sementara di SMK NW Kumbung, tidak ditemukan kendala yang berarti. Semua kegiatan selama 2 hari tersebut berjalan dengan lancar dan kondusif. Dari hasil wawancara para peserta pelatihan didapatkan jawaban bahwa peserta pelatihan memiliki kesiapan mental yang lebih matang ketika menjawab soaldari pada sebelum dilaksanakannya kegiatan pelatihan ini. Para peserta merasa lebih siap menghadapi UNBK yang sesungguhnya, peserta juga menyatakan bahwa para peserta tidak gugup ketika menjawab soal pada saat simulasi dibandingkan sebelum adanya pelatihan, dan daya konsentarasi siswa pelatihan juga meningkat. 
Di SMK NW Renco kegiatan berlangsung sangat kondusif, dibandingkan sekolah lain. Hal ini dikarenakan peserta kegiatan paling sedikit. Pihak sekolah juga menyambut kegiatan ini dengan sangat positif, terlihat dengan besarnya antusiasme pihak sekolah dalam memberikan tanggapan saat pelaksanaan pelatihan ini. Ruangan yang digunakan sebagi tempat pelaksanaan pelatihan adalah laboratorium TKJ yang cukup memadai, baik dari segi spesifikasi komputer yang digunakan maupun jaringan internet yang tersedia.

Kegiatan pelatihan ini berdampat positif untuk siswa yang mengikuti kegiatan ini di ketiga lokasi. Hal ini membuktikan bahwa pelatihan simulasi UNBK dapat membantu persiapan siswa untuk menghadapi UNBK tahun 2017 yang akan datang (Arifianto \& Atmadji, 2016).

\section{SIMPULAN}

Kegiatan pelatihan CBT sebagai simulasi ujian nasional dapat dilaksanakan dengan baik dan berjalan dengan lancar sesuai dengan rencana kegiatan yang telah disusun meskipun ada beberapa kendala yang ditemukan. Kegitan ini juga mampu meningkatkan pengetahuan dan kemampuan siswa dalam memahami proses dan cara kerja system dan aplikasi UNBK, sehingga siswa lebih siap dalam menghadapi UNBK tahun 2017, sesuai dengan tujuan awal PkM. Kegiatan ini mendapat sambutan yang sangat baik dari pihak sekolah, terbukti dengan harapan pihak sekolah tempat pelaksanaan kegiatan berharap tim PKM dapat terus melaksanakan kegiatan di sekolah secara berkelanjutan.

\section{PERNYATAAN PENULIS}

Artikel ini belum pernah dipublikasikan pada jurnal manapun.

\section{DAFTAR PUSTAKA}

Arief, R., \& Suryani, E. (2016). Sistem Dinamik Ujian Nasional Berbasis Komputer Untuk Meminimalkan Resiko Kecurangan Serta Meningkatkan Efektifitas Dan Efisiensi Anggaran. INTEGER: Journal of Information Technology.

Arifianto, A. S., \& Atmadji, E. S. (2016). Instalasi dan Konfigurasi Server-Client pada Sistem Oprasi Sumber Terbuka untuk Penerapan Computer Based Test pada SMKN 1 Maesan. Prosiding Seminar Hasil Penelitian dan Pengabdian Masyarakan Dana BOPTN Politeknik Negeri Jember (pp. 173-176). Jember: Politeknik Negri Jember.

Basuki, I., \& Hariyanto, M. (2014). Asesmen pembelajaran. Bandung: PT Remaja Rosda Karya.

Bennett, R. E., \& Gitomer, D. H. (2010). Transforming K-12 Assessment: Integrating Accountability Testing, Formative Assessment and Professional Support. In Educational Assessment in The 21 st Century (pp. 43-61). Dordrecht: Springer.

BSNP Indonesia. (2015, 12 23). Retrieved from bsnp-indonesia.org: https://bsnp-indonesia.org/wpcontent/uploads/2015/12/Peraturan-BSNP-No-0034-POS-UN-TP-2015-2016.pdf

Darmawan, D., \& Bariyah, S. H. (2015). Pengembangan E-Learning Berbasis Moodle dan Facebook Pada Mata Pelajaran TIK. Jurnal Teknodik, 227-240.

Hermawan, B. (2016, 4 5). republika.com. Retrieved from Republika: https://republika.co.id/berita/ nasional/umum/16/04/05/o55xog354-unbk-2016-masih-terkendala-gangguan-server 


\section{ABSYARA: JURNAL PENGABDIAN PADA MASYARAKAT \\ BIDANG PENDIDIKAN, SAINS, DAN TEKNOLOGI}

Vol. 1 No. 1, Juli 2020, Hal. 22-32

Kholisho, Y. N., \& Arianti, B. D. (2016). E-learning System Development with Moodle Based as Learning Tool in STKIP Hamzanwadi Selong. International Conference on Elementary and Teacher Education (ICETE) (pp. 544-551). Mataram: Univeritas Hamzanwadi.

LombokFM. (2016, Maret 24). Radio Lombok FM. Retrieved from LombokFM.com: https://lombokfm.com/hanya-1-sma-masuk-daftar-unbk-di-lotim.html

Murdiono, M. (2010). Pelatihan Penggunaan Internet sebagai Media Penelusuran Sumber Pustaka bagi Guru-guru Pendidikan Kewarganegaraan Se-kota Yogyakarta. INOTEKS.

Okezone. (2017, 2 19). news.okezone.com. Retrieved from Okezone: https://news.okezone.com $/ \mathrm{read} / 2017 / 02 / 19 / 65 / 1622274 /$ mendikbud-targetkan-2018-sekolah-di-indonesia-gelar-unbkserentak

Özad, B. E., \& Kutoğlu, Ü. (2010). The use of the internet in media education. The Turkish Online Journal of Educational Technology (TOJET).

Pakpahan, R. (2016). Model Ujian Nasional Berbasis Komputer: Manfaat dan Tantangan. Jurnal Pendidikan dan Kebudayaan, 22-23.

Priyono, F., Kanti, S., Dzulfiqar, I., Amirulloh, I., Alvi, A., \& Rosiyadi, D. (2016). Analisis Sentimen Media Sosial Opini Ujian Nasional Berbasis Komputer menggunakan Metoda Naive Bayes. Journal of Electrical And Electronics Engineering.

Sailan, M. (2016). Persepsi Siswa Tentang Pelaksanaan Ujian Nasional Berbasis Komputer Di Smk Komputer Mutiara Ilmu Makassar. Jurnal Tomalebbi.

Supriyanto, W., \& Muhsin, A. (2008). Teknologi informasi perpustakaan. Kanisius.

Suryadi, S. (2015). Peranan Perkembangan Teknologi Informasi dan Komunikasi dalam Kegiatan Pembelajaran dan Perkembangan Dunia Pendidikan. JURNAL INFORMATIKA, 9-19.

Virtič, M. P. (2012). The role of internet in education. Proceedings of DIVAI 2012-9th International Scientific Conference on Distance Learning in Applied Informatics, (pp. 243-249). Štúrovo, Slovakia. 